Diabetologia 8, 179 - $184(1972)$

(C) by Springer-Verlag 1972

\title{
Ventrolateral Hypothalamic Lesions in Obese-Hyperglycemic Mice (obob)
}

\author{
C. Chlouverakis and L.L. Bernardis \\ E.J. Meyer Mernorial Hospital, Department of Medicine, State University of New York, Buffalo, N.Y. 14215, U.S.A.
}

Received: January 15, 1971, accepted: January 18, 1972

Summary. Bilateral electrolytic lesions were induced on the ventrolateral nucleus (VLN) of obese-hyperglycemic mice (obob) and lean littermates, with or without previous body weight reduction. All lean animals with VLN damage died within the first four post-operative days. In contrast, all obese mice (obob) with no prior body weight reduction recovered following an initial period of aphagia and rapid body weight loss. Three out of five reduced $o b o b$ mice died following VLN lesions. - Two months after the operation the body weight of all lesioned obob mice stabilized at a level significantly lower than that of the "sham" operated obese; their serum immunoreactive insulin and blood glucose levels were also lower. - These data indicate that $o b o b$ mice respond normally to bilateral lesions of VLN and that their excess adiposity, by protecting them during the early post-operative period, facilitates their recovery. The final stabilization of the body weight of lesioned $a b o b$ at a level lower than that of control mice is compatible with the view that the VLN acts as the low set point controller in the regulation of body weight.

Lésions ventrolatérales de l'hypothalamus chez des souris obèses hyperglycémiques (obob)

Résumé. Des lésions électrolytiques bilatérales du noyau ventrolatéral (VLN) ont été pratiquées chez des souris obèses-hyperglycémiques (obob) et chez des souris de même portée non-obèses, avec ou sans réduction pondérale préalable. Tous les animaux maigres porteurs de lésions VLN décédèrent dans les quatre premiers jours post opératoires. Au contraire, toutes les souris obèses (obob) sans réduction pondérale préalable récupérèrent après une courte période d'aphagie et de perte de poids. Trois des einq souris $o b o b$ préalablement soumises à un régime amaigrissant succombèrent après lésion du VLN. Deux mois après l'opération, le poids de tous les obob porteurs de lésions du VLN atteignit un niveau stable mais significativement inférieur à celui des animaux soumis à une opération simulée. Il en fut de même du taux d'insuline immunoréactive et du glucose sanguin. -
Ces résultats indiquent que la réponse des obob aux lésions bilatérales du VLN est normale et que leur excès de tissu adipeux les protège dans la période post opératoire et facilite leur récupération. La stabilisation du poids des $a b o b$ à un niveau inférieur à la normale est compatible avec l'hypothèse que le VLN contrôle la limite inférieure du poids.

Ventrolaterale hypothalamische Läsionen bei obes-hyperglykämischen Mäusen (obob)

Zusammenfassung. Bilaterale electrolytische Läsionen wurden in den ventrolateralen Kernen (VLN) von obeshyperglykämischen Mäusen (obob) und normalen Wurfgeschwistern mit oder ohne vorherige Gewichtsreduktion vorgenommen. Alle normalen Mäuse mit VLN-Läsionen starben innerhalb von vier Tagen nach der hypothalamischen Operation. Im Gegensatz dazu erholten sich alle fetten Mäuse (obob), deren Gewicht vor der hypothalamischen Operation nicht reduziert worden war, nach einer Periode von Aphagie und rapidem Gewichtsverlust. Drei von fünf gewichtsreduzierten obob-Mäusen starben nach der VLN-Operation. - Zwei Monate nach der Operation stabilisierten sich die Gewichte aller operierten obob-Tiere auf einem statistisch signifikant niedrigeren Niveau, als dem der scheinoperierten fetten Mäuse entsprach. Immunoreaktives Insulin und Blutglucose waren bei diesen Tieren ebenfalls erniedrigt. - Die Ergebnisse deuten darauf hin, daß obob-Mäuse eine normale Reaktion auf die bilaterale Zerstörung der VLN zeigen und daß die überschüssige Fettmasse zu ihrer Erholung beitrug, indem sie ihnen in der Zeit unmittelbar nach der Operation Schutz gewährte. Die spätere Gewichtsstabilisation der $o b o b$ auf einem subnormalen Niveau ist mit der gegenwärtigen Ansicht zu vereinbaren, daß die ventrolateralen hypothalamischen Kerne als die Regulatoren der unteren Körpergewichtsgrenze dienen.

Key words: Obese-hyperglycemic mice, ventrolateral nucleus, hypothalamus, obesity, serum insulin, blood glucose.
The pathogenetic mechanisms operating in the development of the obese-hyperglycemic syndrome in the mouse (obob) are still unclear. Thus, despite the claim that the lack of a normal pancreatic factor or factors may account for the whole syndrome (Strautz, 1970), there is eircumstantial evidence suggesting that the obesity is due to an alteration of the lipostat (Chlouverakis, 1970; Chlouverakis, 1972), in accordance with the lipostatic theory of obesity (Kennedy, 1952). The presence of sterility, which seems to be due to a lack of pituitary gonadotrophins (Lane, 1959; Runner, 1954), would be compatible with a primary central, i.e. hypothalamic-hypophyseal, rather than a pancreatic cause.

However, the literature concerning studies in $o b o b$ mice of the two hypothalamic centers known to be involved in the regulation of food intake, namely the ventromedial and ventrolateral nucleus (VMN and VLN respectively), is scanty. Thus, gold-thioglucose induces much smaller lesions in the VMN of $o b o b$ mice than that of lean littermates. These lesions are accompanied by a small increase in the hyperphagia suggesting that the ventromedial nucleus of $o b o b$ is still functional and capable of regulating satiety, 
though to a lesser extent than that of lean mice (Baile et al., 1970). On the basis of experiments involving parabiosis of lean and $o b o b$ with diabetic mice $(\mathrm{db} / \mathrm{db})$ Coleman and Hummel (1971) suggested that obesehyperglycemic mice have a normal VMN and satiety center.

On the other hand, studies involving lesions of the ventrolateral nucleus (VLN) of obob are completely lacking. Electrolytic lesions of this nucleus have been weight reduction prior to the lesion of VLN shortened or even abolished the period of aphagia until, finally, the body weight of the lesioned animal plateaued at a level lower than that of the control (Powley and Keesey, 1970).

The lack of any information regarding the response of $o b o b$ mice to bilateral lesions of their ventrolateral nucleus (VLN) prompted us to undertake the present study in which electrolytic lesions were induced

a)

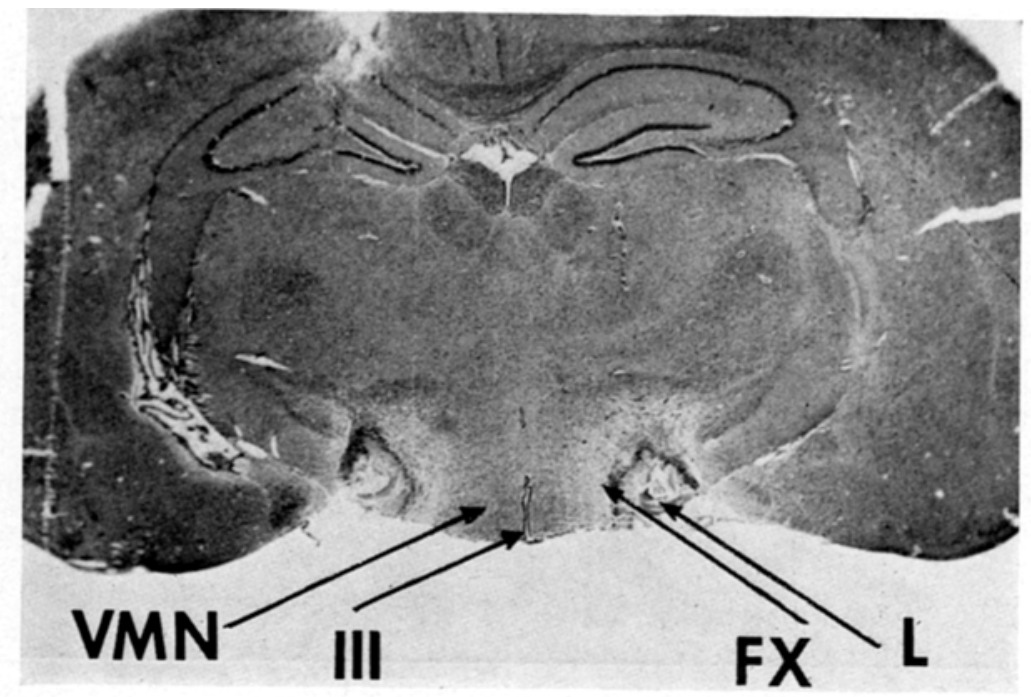

b)

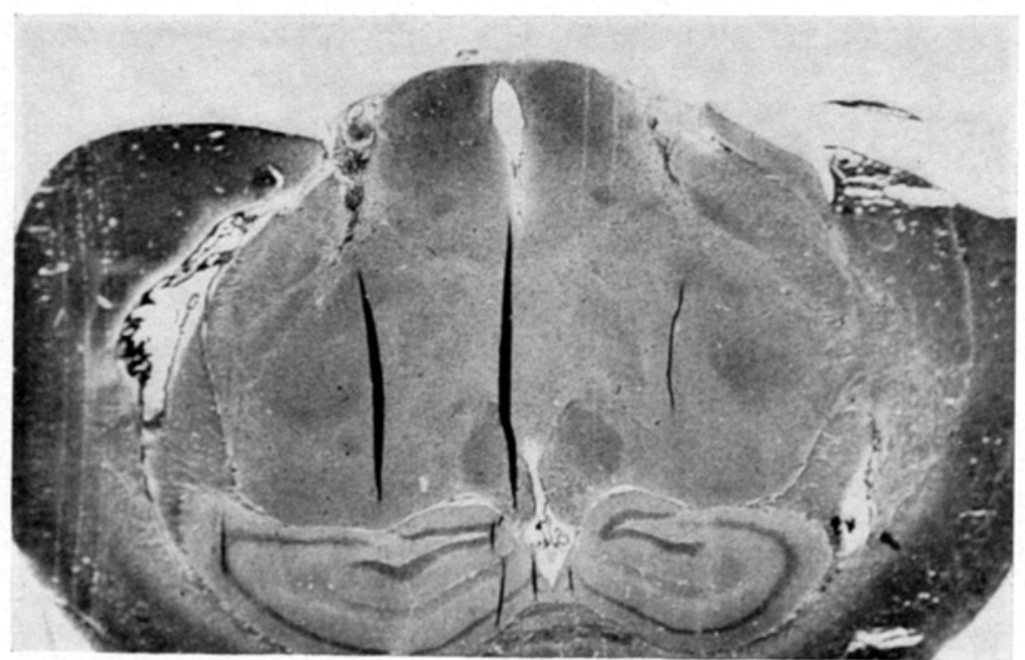

Fig. 1. Low power microphotographs $(12.8 \times$, Cresyl Violet) showing coronal sections of the tuberal region of two representative obob mice with lesions in the lateral hypothalamic area. Abbreviations: III: third ventricle; VMN: ventromedial hypothalamic nucleus; FX: fornix; L: lesion

known to induce aphagia and adipsia in the rat and other species, hence its name as the feeding center (Teitelbaum and Epstein, 1962). In a recent study, however, it was claimed that the aphagia which follows damage of the ventrolateral nucleus (VLN) of rats resulted not from a failure of the animal to eat but from a chronic reduction in the level of weight regulation. This claim was based on experiments in which on the VLN of $o b o b$ and lean mice fed either ad libitum or having been reduced by caloric restriction prior to operation.

\section{Materials and Methods}

Female obese-hyperglycemic mice (obob) and their lean littermates $(\mathrm{ObOb}$ or $\mathrm{Obob})$ were purchased from 
the Jackson Laboratory (Bar Harbor, Maine) and shipped to the laboratory when 3 months old. While in the laboratory they were fed ad libitum a chow mouse/rat diet (Teklad, Inc., Nonmouth, Illinois). When 4 months of age their body weight, blood glucose and serum immunoreactive insulin (IRI) were determined and they were randomly allocated in one of the following groups:

Number of Mice $o b o b$ lean

1. Ad libitum feeding was continued for 43 days and then VLN was lesioned bilaterally. 8

2. Ad libitum feeding was continued for 43 days and was followed by "sham" operation.

3 . Caloric restriction for 43 days followed by bilateral VLN lesion. $\quad 12$

4. Caloric restriction for 43 days followed by "sham" operation.

The animals of groups 3 and 4 during the period of caloric restriction had free access to food for only two $1 / 2 \mathrm{~h}$ intervals daily. At the end of the caloric restriction period, blood glucose and serum insulin were

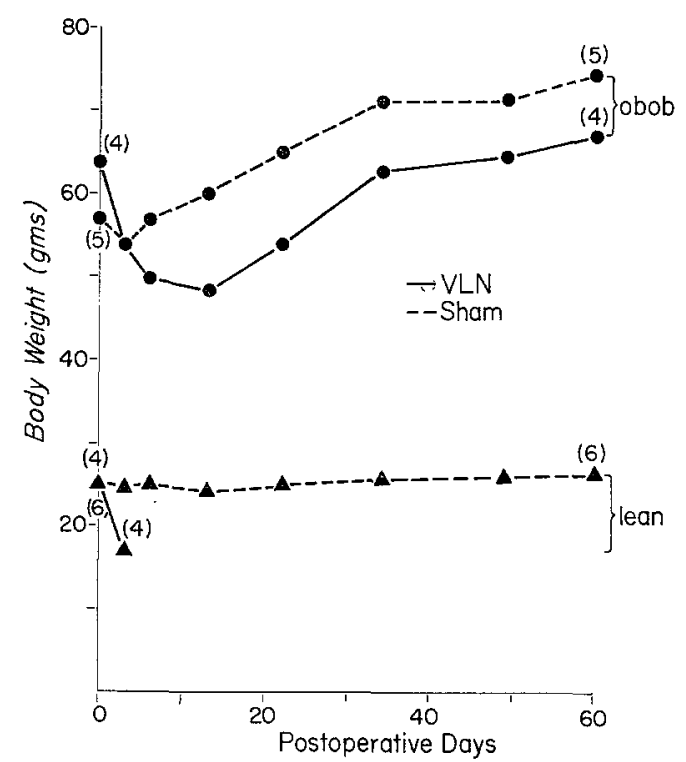

Fig. 2. Body weight (grams) of obese-hyperglycemic mice (obob) and their lean littermates subjected to bilateral electrolytic lesions of VLN or to "sham" operation (at day 0). Numbers in brackets indicate number of (surviving) animals at each time point

determined and the following day the operation involving bilateral VLN lesions was performed as follows: The mice were anesthetized with ether and inserted into a stereotaxic instrument (Baltimore Instrument Company). Holes were drilled into the skull with a dental drill and bilateral lesions were placed in the lateral hypothalamic area using a current of 1.0
$\mathrm{mA}$ which flowed for 5 sec from the bared tip of a $0.25 \mathrm{~mm}$ diameter spar varnish-coated stainless steel electrode. The coordinates used were: $3 \mathrm{~mm}$ anterior of the intraaural line, $1.0 \mathrm{~mm}$ lateral of the mid-sagittal sinus and $5.2 \mathrm{~mm}$ ventral from the vertex. (The authors are grateful to Dr. D.G. Montemurro, University of Western Ontario, for his advice). The incisions were closed with stainless steel clips and the animals returned to their cages. The "sham" operation involved the same procedure except that no current was applied.

Following operation all animals were fed ad libitum and food intake and body weight were measured at 3 day intervals. Two months after the operation the surviving animals were sacrificed by decapitation and blood was collected for blood glucose and serum insulin determination. The brains of all the surviving animals, but also of those which died following the operation, were fixed in $10 \%$ buffered formalin for the subsequent histological analysis of the localization of lesions (Bernardis et al., 1963). Statistical analysis was performed on the data obtained only from animals in which lesions were placed accurately on both ventrolateral nuclei.

The methods of blood sampling, blood glucose and serum insulin (IRI) determinations have been published elsewhere (Chlouverakis and White, 1970a).

\section{Results}

The lesions of the ventrolateral nucleus (VLN) were bilaterally symmetrical and did not impinge on the fornix of the dorsolateral areas of the hypothalamus (Fig. 1). Following such lesions the body weight of the obese-hyperglycemic mice (obob) declined steeply from 63.7 to a low of $48.5 \mathrm{~g}$. None of the lesioned $o b o b$ mice, died however, and after the initial weight loss, their body weight gradually increased and plateaued at the pre-operative level. The body weight of the "sham" operated $o b o b$ mice showed a small and insignificant decline after which it rose, and by termination of the experiment, it stabilized at a level significantly higher than that of the lesioned $a b o b$ mice, despite the fact that at operation their body weight was lower. All lesioned lean animals lost a significant amount of weight and died within the first three postoperative days. There was no effect of the "sham" operation on the body weight of lean mice (Fig. 2).

Reducing the body weight of $o b o b$ mice prior to operation by about $50 \%$ caused the death of three (out of five) lesioned animals post-operatively. The surviving lesioned animals gained in weight, but at termination of the experiment their gain in body weight was still lagging behind that of the "sham" calorically restricted $a b o b$ mice so that the difference in body weight between lesioned and control animals was significantly greater at termination of the experiment than it was both at the onset of caloric restriction and at the time of operation $(p<0.05)$. 
Of the lean animals subjected to body weight reduction prior to operation only two had histologically demonstrable lesions in the VLN and both died during the first four post-operative days. By contrast, the operative days, with the exception of the reduced obese whose food intake, though markedly reduced, was significantly different from zero $(p<0.02)$ and was similar to that of the reduced control $a b o b$ mice. After



Fig. 3. Body weight (grams) of obese-hyperglycemic mice (obob) and their lean littermates subjected to body weight reduction and then to either electrolytic lesions of VLN or to "sham" operation. Numbers in brackets indicate number of (surviving) animals at each time point

Table 1. Daily food consumption (grams, mean $\pm S E M$ ) of obob and lean control mice following bilateral lesions of the ventrolateral nucleus (VLN). Reduced animals were mice whose body weight was reduced prior to the operation by caloric restriction. Daity food consumption of the ad lib fed mice prior to the operation was $5.95+0.15$ and $3.73 \pm 0.09$ for obob and lean mice respectively. Numbers in brackets indicate the number of animals

\begin{tabular}{|c|c|c|c|c|}
\hline \multicolumn{4}{|c|}{ Post-operative Days } & $13-22$ \\
\hline VLN lesioned & $0.00 \pm 0.00$ & $\begin{array}{l}o b o b \\
0.65 \pm 0.44\end{array}$ & $2.02 \pm 1.24$ & $5.32 \pm 0.81$ \\
\hline "sham" operated & $0.78 \pm 0.54$ & $3.76 \pm 1.20$ & $5.52 \pm 0.72$ & $5.89 \pm 1.75$ \\
\hline $\begin{array}{l}\text { Reduced, } \\
\text { lesioned }\end{array}$ & $\begin{array}{l}1.36 \pm 0.43 \\
(5)\end{array}$ & $\begin{array}{l}2.40 \pm 1.31 \\
(3)\end{array}$ & $\begin{array}{l}3.87 \pm 1.97 \\
(3)\end{array}$ & $\begin{array}{l}6.53 \pm 2.26 \\
(3)\end{array}$ \\
\hline $\begin{array}{l}\text { Reduced "sham" } \\
(6)\end{array}$ & $1.38 \pm 0.43$ & $3.10 \pm 0.95$ & $6.05 \pm 0.58$ & $6.83 \pm 0.13$ \\
\hline $\begin{array}{l}\text { VLN lesioned } \\
\text { (4) }\end{array}$ & $0.00 \pm 0.00$ & $\begin{array}{l}\text { lean } \\
-\end{array}$ & - & - \\
\hline $\begin{array}{l}\text { "sham" operated } \\
(6)\end{array}$ & $4.00 \pm 0.22$ & $4.20 \pm 0.32$ & $3.95 \pm 0.24$ & $3.24 \pm 0.71$ \\
\hline $\begin{array}{l}\text { Reduced, } \\
\text { lesioned } \\
(2)\end{array}$ & $0.00 \pm 0.00$ & - & - & - \\
\hline $\begin{array}{l}\text { Reduced "sham" } \\
(7)\end{array}$ & $3.25 \pm 0.45$ & $4.45 \pm 0.35$ & $4.40 \pm 0.50$ & $4.35 \pm 0.55$ \\
\hline
\end{tabular}

"sham" operated lean animals rapidly put on the weight which was lost by the pre-operative caloric restriction (Fig. 3).

Both lean and obese lesioned mice became aphagic during the day of operation and the first two post- the third post-operative day the food intake of the lesioned obese animals increased gradually, but remained lower than that of the control animals. No subsequent data of food intake are available for lean mice with hypothalamic damage all of which died during the 
first four post-operative days. In contrast, the food intake of the lean control mice was not affected by the "sham" operation (Table 1).

Caloric restriction markedly reduced the blood glucose levels of $a b o b$ but only mildly those of lean mice. Two months after the induction of the lateral of caloric restriction and of the operation on the serum insulin levels; but whereas blood glucose was significantly lower two months post-operatively in both lesioned and control reduced mice, only the insulin levels of the reduced, lesioned obese animals remained consistently low (Table 3).

Table 2. Blood glucose ( $\mathrm{mg} / 100 \mathrm{ml}$, mean $\pm S E M)$ of obob and lean control mice fed ad libitum, calorically restricted for 20 days and after 2 months of bilateral lesions in the ventrolateral nucleus (VLN) or "sham" operation. Numbers in brackets indicate the number of animals

\begin{tabular}{|c|c|c|c|}
\hline & $\begin{array}{l}\text { During ad libi- } \\
\text { tum feeding } \\
\text { obob }\end{array}$ & $\begin{array}{l}\text { During caloric } \\
\text { restriction }\end{array}$ & $\begin{array}{l}2 \text { months after } \\
\text { operation }\end{array}$ \\
\hline $\begin{array}{l}\text { VLN, lesioned } \\
\text { (4) }\end{array}$ & $190.0 \pm 27.9$ & - & $156.5 \pm 29.8$ \\
\hline $\begin{array}{l}\text { "sham" operated } \\
\text { (5) }\end{array}$ & $188.3 \pm 12.4$ & - & $221.6 \pm 58.4$ \\
\hline Reduced, VLN lesioned & $\begin{array}{l}203.0 \pm 38.5 \\
(5)\end{array}$ & $\begin{array}{l}58.4 \pm 10.3 \\
(5)\end{array}$ & $\begin{array}{l}130.0 \pm 16.0 \\
(2)\end{array}$ \\
\hline $\begin{array}{l}\text { Reduced "sham" } \\
(6)\end{array}$ & $239.8 \pm 35.5$ & $74.3 \pm 5.2$ & $155.7 \pm 12.6$ \\
\hline $\begin{array}{l}\text { VLN, lesioned } \\
\text { (4) }\end{array}$ & $\begin{array}{l}\text { lean } \\
144.5 \pm 6.1\end{array}$ & - & - \\
\hline $\begin{array}{l}\text { "sham" operated } \\
(6)\end{array}$ & $135.3 \pm 6.8$ & - & $111.3 \pm 4.1$ \\
\hline $\begin{array}{l}\text { Reduced, VLN lesioned } \\
\text { (2) }\end{array}$ & $123.5 \pm 4.6$ & $114.0 \pm 9.5$ & - \\
\hline Réduced "sham" & $\underset{(8)}{118.6 \pm 5.1}$ & $\begin{array}{l}112.6 \pm 3.5 \\
(8)\end{array}$ & $\begin{array}{l}124.0 \pm 0.0 \\
(2)\end{array}$ \\
\hline
\end{tabular}

Tablo 3. Serum immunoreactive insulin ( $\mu U / m l$, mean $\pm S E M)$ of obob and lean control mice fed ad libitum, calorically restricted for 20 days and after 2 months of bilateral lesions in the ventrolateral (VLN) or sham operation. Numbers in brackets indicate the number of animals

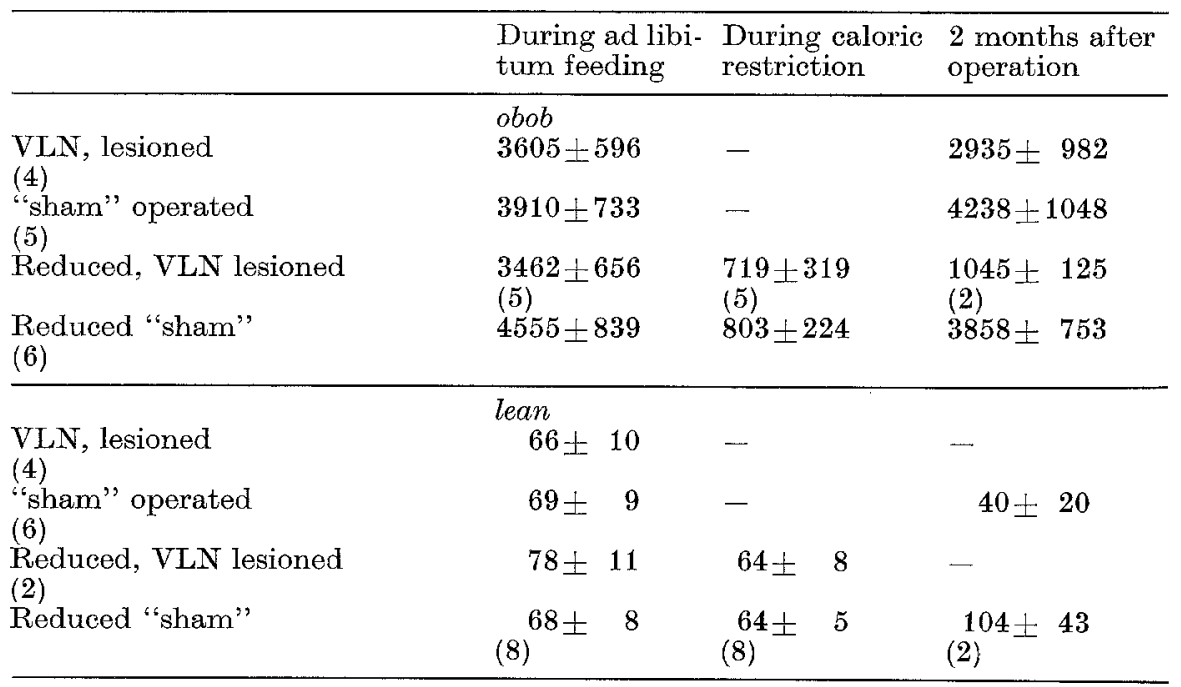

hypothalamic lesion, the blood glucose was still significantly lower than preoperatively in the reduced obob, but it did not differ significantly from that of the reduced "sham" operated mice (Table 2).

Similar to the effect on blood glucose was the effect

\section{Discussion}

This study has shown that the obese-hyperglycemic mice (obob) respond to electrolytic damage of their ventrolateral nuclei by aphagia and rapid fall of 
body weight. This response is similar to that described in the rat, in which bilateral VLN damage is accompanied by aphagia of sufficient duration to cause the death of the animal (Teitelbaum and Epstein, 1962). Consistent with this view is the finding reported in this paper according to which all lean mice bearing bilateral lesions of the VLN died within the first three post-operative days. In contrast, none of the lesioned obob mice died, suggesting that obesity exerts a protective action, the obese animal surviving the rapid and prolonged body weight loss resulting from the damage of the VLN. The post-operative loss of body weight of the two lean animals reduced prior to lesioning was much less than that of the non-reduced lean mice. However, these mice, too, died within the first four days following the operation. Similarly, $a b o b$ mice whose body weight was reduced by $50 \%$ prior to lesioning lost less weight post-operatively than non-reduced lesioned $o b o b$ mice; but only two out of five were alive at termination of the experiment. Thus, owing to the early post-operative death of all lesioned lean mice, no data are available to allow conclusions regarding the hypothesis of Powley and Keesey. These authors have proposed that the weight loss following bilateral hypothalamic lesions of rats reflects an active regulatory process, the effect of the lesion consisting in an alteration of the level of weight regulation (Powley and Keesey, 1970).

On the other hand, the high recovery rate of $o b o b$ mice bearing lateral hypothalamic lesions allow more meaningful conclusions. Thus, not only did reduced $o b o b$ lose less body weight than non-reduced $a b o b$ mice following bilateral VLN lesioning, but all the ones (reduced and non-reduced) which recovered from the initial weight loss stabilized at body weights below those of controls. Thus, inasmuch as the ventrolateral nucleus acts as the lower limit of the lipostat, $o b o b$ mice seem to respond normally to lesions of this nucleus.

The post-operative changes in body weight of $o b o b$ mice were probably the result of similar changes of food intake. The reduced food intake of "sham" operated $o b o b$ mice during the first two post-operative days was probably due to the stress of the operation. No such reduction of food intake was observed in the sham-operated lean mice, which is further evidence of the better response of the latter to stress.

The response of obese-hyperglycemic mice to bilateral electrolytic lesions of ventromedial nucleus (VMN) are presently under investigation in this laboratory. Regarding this nucleus, circumstantial evidence suggests that it too may respond normally in $o b o b$ mice. Thus, obese-hyperglycemic mice gain weight after injection of gold-thioglucose (Baile et al., 1970) and have a response similar to that of lean mice when parabiosed with diabetic mice $(\mathrm{db} / \mathrm{db})$ whose VMN appears to respond abnormally (Coleman and Hummel, 1971).
This evidence and the data presented in this paper suggest that the regulation of body weight or body fat in $a b o b$ is normal, though shifted to a higher level (Chlouverakis, 1972). The decrease of blood glucose and serum insulin levels in $o b o b$ bearing lateral hypothalamic lesions suggests an improvement of the insulin resistance. Whether this is due to the weight reduction, as shown in previous studies (Chlouverakis and White, 1970), or is independent of it cannot be established on the basis if the present experiments.

Acknowledgement. This work was supported by research grant No. GR-32-MM-71 of the United Health Foundation of Western New York and by a Buswell Fellowship. We are grateful to Mr. David Kolody and Mrs. Betty Stone for their excellent technical assistance.

\section{References}

Baile, C.A., Herrera, M. G., Mayer, J.: Ventromedial hypothalamus and hyperphagia in hyperglycemic obese mice. Amer. J. Physiol. 218, 857-863 (1970).

Bernardis, L.L., Box, B.M., Stevenson, J.A. F.: Growth following hypothalamic lesions in the weanling rat. Endocrinology 72, 684-692 (1963).

Chlouverakis, C.: Induction of obesity in obese-hyperglycaemic mice on normal food intake. Experientia 26, $1262-1263(1970)$.

- White, P.A.: Obesity and insulin resistance in the obese-hyperglycemic mouse (obob). Metab. 18, 9981006 (1970a).

- Effect of caloric restriction on body weight loss and body fat utilization in the obese-hyperglycemic mice (obob). Metab. 21, 10-19 (1972).

Coleman, D.L., Hummel, K.P.: Comparison of the obesity syndromes of obese $(\mathrm{ob} / \mathrm{ob})$ and diabetic $(\mathrm{db} / \mathrm{db})$ mice. Symposium: Obese-hyperglycemic mice, Dept. of Biochem. Imperial College of Science and Technology, London, July 1971.

Kennedy, G.C.: The role of depot fat in the hypothalamic control of food intake in the rat. Proc. roy. Soc. Med. Series B 140, 578-592 (1952).

Lane, P.W.: The pituitary-gonad response of genetically obese mice in parabiosis with thin and obese siblings. Endocrinology 65, 863-868 (1959).

Powley, T.L., Keesey, R.E.: Relationship of body weight to the lateral hypothalamic feeding syndrome. J. comp. physiol. Psychol. 70, 25-36 (1970).

Runner, M.N., Gates, A. : Sterile obese mothers. J. Hered. 45, 51-55 (1954).

- Inherited hypofunction of the female pituitary in the sterile-obese syndrome in the mouse. Genetics 39, 990$991(1954)$.

Strautz, R.L.: Studies of hereditary-obese mice (obob) after implantation of pancreatic islets in millipore filter capsules. Diabetologia 6, 306-312 (1970).

Teitelbaum, P., Epstein, A.M.: The lateral hypothalamic syndrome. Psychol. Rev. 69, 74-90 (1962).

C. Chlouverakis, M.D., State University of New York at Buffalo,

Department of Medicine, E.J. Meyer Memorial Hospital, 462 Grider Street,

Buffalo, N.Y. 14215, U.S.A. 